\title{
Two-dimensional zymography in detection of proteolytic enzymes in wheat leaves
}

\author{
Małgorzata Grudkowska $\cdot$ Piotr Lisik \\ Krystyna Rybka
}

Received: 27 March 2013/Revised: 13 August 2013/Accepted: 27 August 2013/Published online: 12 September 2013

(C) The Author(s) 2013. This article is published with open access at Springerlink.com

\begin{abstract}
Proteolytic enzymes in wheat leaves were studied using zymographic detection of enzyme activities on one-way (1D) SDS-polyacrylamide gels and twodimensional (2D) ones, on which protein samples were isoelectrofocused prior to PAGE separation. Gelatin of concentration $0.1 \%$, copolymerized into SDS-PAGE gels, digested by active proteinases enabled detection of those enzymes. On 1D gels, seven bands were seen and assigned to particular families through the use of specific inhibitors. Metalloproteinases inhibited by $20 \mathrm{mM}$ EDTA were detected as $150 \mathrm{kDa}$ band; aspartic proteinases were assigned to $115-118 \mathrm{kDa}$ double band by using $25 \mathrm{mM}$ pepstatin; $10 \mathrm{mM}$ phenylmethylsulfonyl fluoride used for detection of serine proteinases pointed to band of $70 \mathrm{kDa}$ and finally due to $10 \mu \mathrm{M} \mathrm{E}-64$ inhibitor, cysteine proteinases of 37 and $40 \mathrm{kDa}$ were detected. On 2D gels, additional separation according to protein isoelectric points enabled detection of proteinase isoforms. In the range of 4.5-6 $\mathrm{p} I$, six metalloproteinases as well as ten aspartic proteinases were visible, ten serine- isoforms of $\mathrm{p} I$ 4.5-6.8 and four cysteine proteinases of 4.5-5.0 $\mathrm{p} I$ were found. Presented results were detected as reproducible results observed at least in four independent biological replications.
\end{abstract}

Communicated by M. Stobiecki.

M. Grudkowska $(\square) \cdot$ P. Lisik

Department of Biochemistry, Faculty of Agriculture and

Biology, Warsaw University of Life Sciences, SGGW,

Nowoursynowska 159, 02-776 Warsaw, Poland

e-mail: malgorzata_grudkowska@sggw.pl

K. Rybka

Plant Physiology and Biochemistry Department, Plant Breeding and Acclimatization Institute-National Research Institute, Radzików, 05-870 Błonie, Poland
Keywords 1D zymography · 2D zymography · Proteinases · Wheat

\section{Introduction}

Zymography is a widely accepted analytical technique used to detect enzymes in tissue extracts. It is based on visualization of areas where the specific substrate is digested by the enzyme of interest. It can be used to perceive the total enzymatic activity or to see activities of enzyme isoforms following the protein electrophoretical separation on polyacrylamide gels (Vandooren et al. 2013).

The most popular systems, arranged in a hierarchy of Google search results, have been elaborated for detection of: phosphatases (Robinson and Glew 1980), reactive oxygen species scavenging enzymes: catalases, superoxide dismutases, peroxidases (Shukla et al. 2009; Srivalli and Khanna-Chopra 2001), amylases (Steup and Gerbling 1983) and proteinases (Lantz and Ciborowski 1994). Furthermore, the system has been successfully used for detection of glycohydrolases: glucanases and glucosidases, xylanases, mannases, hemicellulases, cellulases and ligninases (Joo et al. 2009; Royer and Nakas 1990; Sakamoto and Toyohara 2009) as well as esterases, lipases (Kwon et al. 2011) and nucleases (Cazenave and Toulme 2001). A crucial role in detection of enzymes activities using zymography play inhibitors. For detection of proteolytic enzymes, for example, the comparison of gel patterns from the substrate digestion without the use of inhibitor to gels on which digestion was carried out in the presence of specific inhibitor allows the identification of a band that corresponds to the enzyme of interest.

Most commonly, for proteinase activity detection after denaturing but nonreducing electrophoresis, protein 
renaturation is followed by substrate digestion (Zhang and Jones 1995). All of these are carried out in the gel soaked in a buffer of $\mathrm{pH}$ appropriate to the $\mathrm{pH}$ optimum of studied enzyme. A modification of this method is the detection of proteinase inhibitors in the gel. While such a gel is incubated in a buffer containing the enzyme of interest nearly the whole substrate incorporated into the gel is digested beside the places where enzyme inhibitors are present. Such a method is commonly used to detect metalloproteinase inhibitors and is named reverse zymography (Hawkes et al. 2010). Usage of fluorescence-labeled matrix protein improved this technique by enabling the in situ inhibitor visualization, in histological sections (George and Johnson 2010).

Even though the progress in proteomic methods is rapid, zymography still has many advantages. This method is relatively cheap and fast, moreover, it enables immediate location of studied enzymes. However, in some cases, separation of protein from the gel is less accurate. When high intensity patterns are detected some isoforms of the protein could not be visible. Proteins could migrate slower through the gel containing substrate, influencing on molecular weight overestimation. On the other hand, conditions of extraction and electrophoresis may influence the reduction of enzyme activities leading to underestimation of their amount (Pan et al. 2011). In this short communication, we report the advantage of using two-dimensional (2D) zymography in combination with specific proteinase inhibitors to reveal the pattern of major leaf proteases in wheat. We demonstrate that zymography is still the technique of choice in protease studies and permits very good separation of distinct proteinase families.

\section{Materials and methods}

\section{Plant material}

The experiments were carried out on 10-day-old seedlings of spring wheat (Triticum aestivum L.) Ethos cult $_{\text {, grown as }}$ described previously (Grudkowska and Zagdanska 2010). In brief: fourfold replica of 25 germinated grains were placed side by side between double filter paper strips, rolled up and grown in plastic boxes in a climatic chamber at conditions of day/night temperature $18 / 14{ }^{\circ} \mathrm{C}$, photoperiod $16 / 8 \mathrm{~h}$, photosynthetic photon flux density: $260 \mu \mathrm{mol} \mathrm{m} \mathrm{m}^{-2} \mathrm{~s}^{-1}$ and $70-80 \%$ air humidity. Seedlings were fertilized with Knopp solution supplemented with Hoagland's micronutrients.

\section{Protein extraction}

Prior to extraction, $300 \mathrm{mg}$ of leaves were ground in liquid nitrogen followed by grinding in $1 \mathrm{ml}$ of extraction buffers:
(1) denaturing non-reducing lysis buffer containing primarily $6 \mathrm{M}$ urea, $2 \mathrm{M}$ thiourea, $0.05 \%$ CHAPS $0.5 \%$ and carrier ampholytes (BioRad, Bio-Lytes pI 3-10), according to the BioRad Manual and in subsequent experiments in the buffer with amount of urea decreased to $4 \mathrm{M}$ to improve zymography results, or (2) non-denaturing non-reducing $50 \mathrm{mM}$ sodium acetate buffer of $\mathrm{pH} 5$ containing $1 \mathrm{mM}$ EDTA and $2 \mathrm{mM}$ cysteine, common for vacuolar protein extraction prior to one-dimensional (1D) electrophoresis (Zhang and Jones 1995). Extractions were followed by $15 \mathrm{~min}$ centrifugation at $4{ }^{\circ} \mathrm{C}$ and $15,000 \mathrm{~g}$. Soluble proteins were precipitated from the supernatant with $100 \%$ ice-cooled acetone, separated by centrifugation for $10 \mathrm{~min}$ at $15,000 \mathrm{~g}, 4^{\circ} \mathrm{C}$, washed twice in $80 \%$ acetone, air-dried and stored at $-80{ }^{\circ} \mathrm{C}$ until used.

\section{IEF and SDS-PAGE-electrophoresis}

For isoelectric focusing (IEF), two types of buffer were used alternatively: (1) denaturing non-reducing: $4 \mathrm{M}$ urea, $2 \mathrm{M}$ thiourea, $0.5 \%$ CHAPS, $0.001 \%$ bromophenol blue, $0.25 \%$ carrier ampholytes (BioRad, Bio-Lytes pI 3-10), or (2) nondenaturing non-reducing IEF sample buffer containing $1 \%$ NP-40, $5 \%$ glycerol, $0.001 \%$ bromophenol blue, $0.25 \%$ carrier ampholytes (BioRad, Bio-Lytes pI 3-10). IPG-Dalt strips (BioRad) in the $\mathrm{pH}$ range 4-7 were rehydrated overnight under passive conditions. Each of the operation was carried in one of the two rehydratation buffers. $60 \mu \mathrm{g}$ of protein (determined spectrophotometrically at $595 \mathrm{~nm}$ by Bradford method with BSA as a standard) was carried out on the Immobiline Dry Strip. For PAGE electrophoresis, protein was dissolved in distilled water and mixed 1:1 with SLB.

Isoelectric focusing (IEF) was ran using a Biorad PROTEAN IEF focusing chamber at a constant temperature of $20{ }^{\circ} \mathrm{C}$ and at $50 \mu \mathrm{A} /$ strip for $20 \mathrm{~min}$ at $250 \mathrm{~V}$ followed by a $2 \mathrm{~h}$ linear ramping to $4,000 \mathrm{~V}$ and final focus until the value of $10,000 \mathrm{Vh}$ was reached. Strips were frozen and the next day were equilibrated in $50 \mathrm{mM}$ Tris- $\mathrm{HCl}$ incubation buffer, $\mathrm{pH}$ 6.8, containing $4 \mathrm{M}$ urea, $30 \%$ glycerol, $2 \%$ SDS for $15 \mathrm{~min}$. After equilibration, strips were sealed on the top of $10 \%$ SDS-PAGE gels using $0.5 \%$ agarose in $0.1 \mathrm{M}$ Tris$\mathrm{HCl} \mathrm{pH} 6.8$ containing $0.001 \%$ bromophenol blue. SDSPAGE was run on $10 \%$ acrylamide gels with $0.1 \%$ gelatin copolymerized prior to zymography, in $50 \mathrm{mM}$ Tris-Cl buffer $\mathrm{pH} 6.8$, at constant amperage of $20 \mathrm{~mA} / \mathrm{gel}$ (mini-gel $80 \mathrm{~mm} \times 60 \mathrm{~mm} \times 0.75 \mathrm{~mm})$ until the blue dye front reached the bottom of the gel. Molecular weight standard PageRuler ${ }^{\mathrm{TM}}$ (Thermo SCIENTIFIC) was used for electrophoresis in 2nd dimension.

\section{Zymography}

Reactivation of protein after electrophoretical separation was achieved by the double incubation of gels in $2.5 \%$ 
Tween 20 for 30 min. Afterward gels were briefly rinsed three times with distilled water followed by $16 \mathrm{~h}$ incubation in $50 \mathrm{mM}$ acetic buffer $\mathrm{pH} 5.0$ containing $2 \mathrm{mM}$ cysteine prior to digestion of copolymerized gelatin by proteolytic enzymes. Incubations were carried out with gentle shaking at $25^{\circ} \mathrm{C}$. Gels were then rinsed with water as before and stained for $3 \mathrm{~h}$ in staining solution $(0.5 \%$ amido black, $30 \%$ methanol, $10 \%$ acetic acid). Finally, gels were destained in solution of $30 \%$ methanol and $10 \%$ acetic acid until clear bands were visible on a dark blue background. To detect proteinase specificity enzyme, inhibitors were used: $20 \mathrm{mM}$ EDTA for metalloproteinases (EC 3.4.24), $25 \mathrm{mM}$ pepstatin for aspartic proteinases (EC 3.4.23), $10 \mathrm{mM}$ phenylmethylsulfonyl fluoride (PMSF) for serine proteinases (EC 3.4.21), and $10 \mu \mathrm{m}$ E-64 for inhibition of cysteine proteinases (EC 3.4.22) (Zhang and Jones 1995). Protein extracts were incubated for $2 \mathrm{~h}$ in buffer of $\mathrm{pH} 5$, containing appropriate inhibitor prior to electrophoresis, as well as after electrophoreses, the gelatin digestion was carried out in the presence of those inhibitors. The presented results were detected as reproducible results observed at least in four independent biological replications.

\section{Results and discussion}

Since extraction and zymographic detection of proteinases in recommended conditions (Rossano et al. 2011; Wilkesman and Schroder 2007) in denaturing and non-reducing the buffer did not yield expected results showing only four spots of $\mathrm{MW}$ about $70 \mathrm{kDa}$ and differing in $\mathrm{p} I$ (Fig. 1a), protein extraction was performed in nondenaturing, non-reducing environments. In such conditions, seven groups of proteinases differing in MW as well as $\mathrm{p} I$ were detected.

To specify the proteinase families (as named in MEROPS database http://merops.sanger.ac.uk,) or sub-subclasses (according to International Union of Biochemistry and Molecular Biology: IUBMB/1992 www.chem.qmul. ac.uk/iubmb/enzyme/) on 2D zymograms, it was decided to detect the proteinases by zymographic assays performed on 1D gels (Fig. 2). Protein separation by 2D electrophoresis requires two consecutive, discrete steps: IEF followed by SDS-PAGE. The enzyme activity bands as well as their decay in the presence of specific inhibitors are easier to be detected on 1D SDS-PAGE gels than the spots resulted from 2D separation. Since SDS-PAGE in both 1D and 2D separations were run in the same conditions; proteinase family identification was performed on 1D zymograms (Fig. 2) and extrapolated by the 2D technique (Fig. 1b). Zymographic detection of proteinases on the SDS-PAGE gel revealed 7 bands in control leaf extract non-treated by specific inhibitors.
The use of $20 \mathrm{mM}$ EDTA, inhibitor of metalloproteinases (EC 3.4.24), suppressed single, $150 \mathrm{kDa}$ band (EP1). Metalloproteinases are ATP-dependent enzymes, having the divalent cation of zinc, rarely cobalt, in the active center with chaperone-like activity in the ATPase domain. These enzymes are well characterized in mammals as membrane proteins, crucial for housekeeping as well as for recovery from pathological processes (Mariano and Funk 2012). Recently, they have been identified in oligomeric complexes of plant mitochondrial and chloroplastic membranes: in mitochondria, as part of cytochrome $b c l$ and in chloroplasts as part of heterocomplex degrading protein D1, the core protein of photosystem II (PS II). In Arabidopsis, 12 genes encoding proteins homologous to Escherichia coli FtsH metalloproteins were identified (Janska et al. 2013; Lucinski and Jackowski 2013; Piechota et al. 2010; Wagner et al. 2012). In broccoli florets, metalloproteinases of MW $69 \mathrm{kDa}$ were detected by 2D zymography (Rossano et al. 2011). From soybean leaves, Sltil14 gene encoding metalloproteinase of $44 \mathrm{kDa}$ and predicted $5.5 \mathrm{p} I$ was isolated but zymographic detection of protein product was unsuccessful (Cho et al. 2009).

The use of $25 \mathrm{mM}$ pepstatin $\mathrm{A}$, the naturally occurring hexapeptide, highly specific and competitive suppressed aspartic proteinase (EC 3.4.23) double band (EP2-EP3) of molecular weight $115-118 \mathrm{kDa}$. Aspartic proteinases are named based on IUBMB/1992 classification (www.chem. qmul.ac.uk/iubmb/enzyme/) which refers to mechanisms of catalytic reaction. In the MEROPS database, peptidases are grouped into families according to a hierarchical, structurebased classification referring to statistically significant similarities in amino acid sequence further grouped by homology into clans (Rawlings et al. 2012). Aspartic proteinases belong to families C14A (caspases) and C14B (metacaspases) of CD Clan (Misas-Villamil et al. 2013) which makes them the most studied proteinases due to their participation in processes of apoptosis and programmed cell death (PCD) (Chichkova et al. 2012; Marek 2013; Ouyang et al. 2012; Shrestha and Megeney 2012; Tsiatsiani et al. 2011; Wang and Bayles 2013). In wheat grain, aspartic proteinases were detected by Tamura et al. (2007). Authors have mentioned two isoforms of 35 and $27 \mathrm{kDa}$ isolated by affinity chromatography in denaturing conditions. Type II metacaspase from wheat leaves (TaeMCAII) was modeled in silico, cloned and characterized (Piszczek et al. 2011; Piszczek et al. 2012). Studies of Arabidopsis thaliana dwarf mutant, impaired in carbohydrate metabolism, enabled characterization of NANA, chloroplastlocated, aspartic proteinase (Paparelli et al. 2012).

Phenylmethylsulfonyl fluoride (PMSF) is an inhibitor of serine proteinases (EC 3.4.21). Although usually it does not inhibit all serine proteinase activity, due to a short half-life in water solutions, it is commonly used in detection of 
Fig. 1 Zymographic detection of wheat seedling proteinases separated by $2 \mathrm{D}$ electrophoresis in conditions: a denaturing and non-reducing (4 M urea, $2 \mathrm{M}$ thiourea, $0.5 \%$ CHAPS, $0.001 \%$ bromophenol blue, $0.25 \%$ carrier ampholytes) and b non-denaturing and nonreducing ( $1 \% \mathrm{NP}-40,5 \%$ glycerol, $0.001 \%$ bromophenol blue, $0.25 \%$ carrier ampholytes). Spots of detected proteinases are numbered
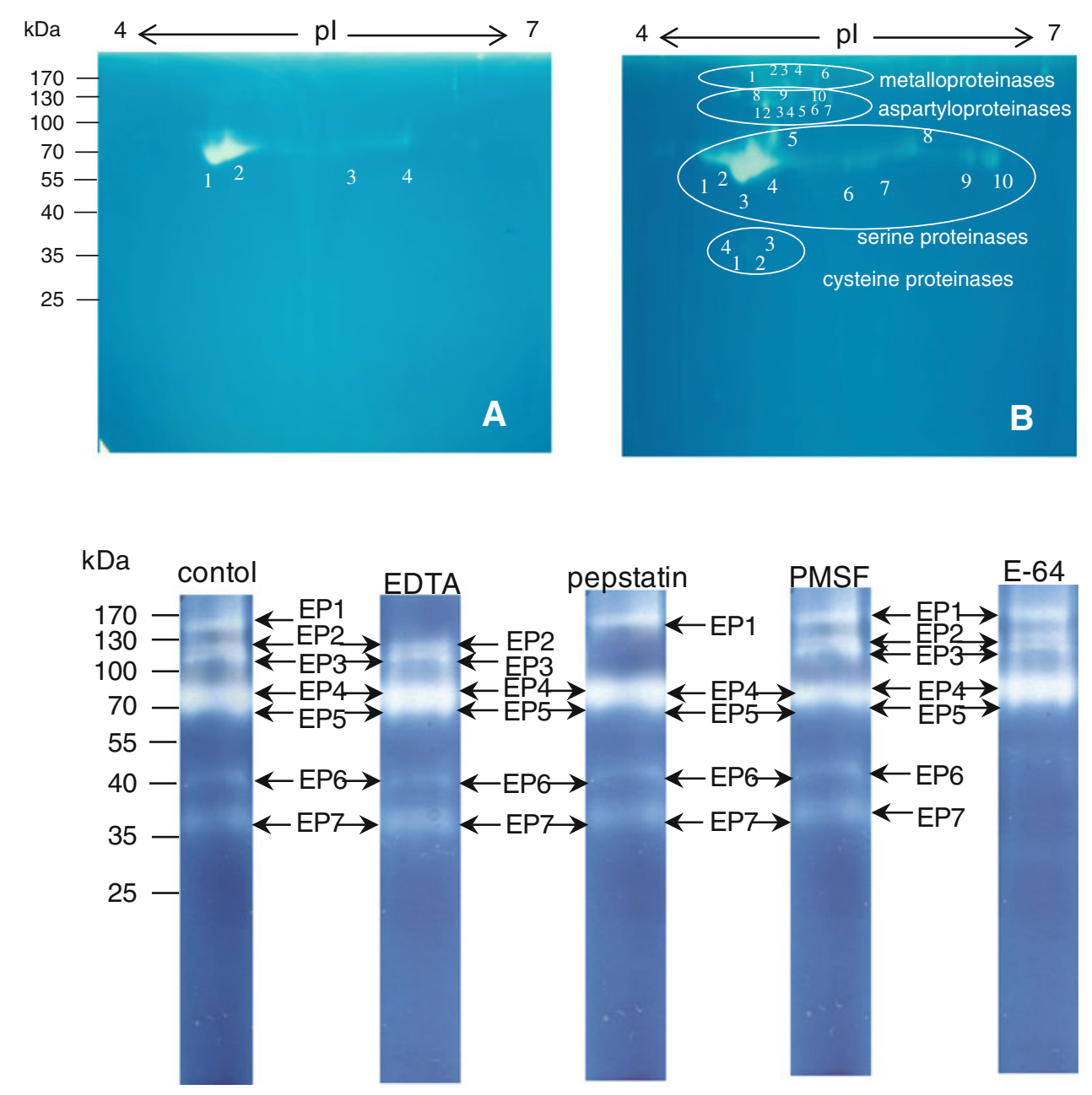

Fig. 2 Zymographic identification of proteases families wheat seedlings on $1 \mathrm{D}$ gels using specific inhibitors: 20 mM EDTA for inhibition of metalloproteinases: $25 \mathrm{mM}$ pepstatin for aspartic proteinases, $10 \mathrm{mM}$ PMSF for serine proteinases and $10 \mu \mathrm{M}$ E-64 for inhibition of cysteine proteinases. Experiment was carried out in non-denaturing non-reducing conditions. Sample non-treated by any inhibitor was a control. Bands of proteinase activities are marked by arrowheads those proteinases. The molecular weights of double EP4 and EP5 bands in which intensity was decreased upon action of this inhibitor is about $70 \mathrm{kDa}$. Rossano et al. (2011) detected $56 \mathrm{kDa}$ bands of serine proteinase in senescence broccoli florets. In spinach chloroplasts, two subunits of alkaline serine proteinase characterized by molecular weights 63 and $32 \mathrm{kDa}$ and maximal activity in $50{ }^{\circ} \mathrm{C}$ at $\mathrm{pH} 8.5$ were purified using the HIC-HPLC system. When separated on native PAGE, only a single band of $95 \mathrm{kDa}$ was visible (Srivastava et al. 2009). Acting in parallel to the carboxy-terminal processing proteinase CtpA and the ATP-dependent thylakoid-bound metalloproteinase FtsH, the serine-type proteinase DegP is critical for the biogenesis and maintenance of PSII (Chi et al. 2012).

The irreversible inhibitor of cysteine proteinases, E-64, that binds covalently to the enzyme reactive center was used to detect their bands on a 1D zymogram. Disappearance of EP6 and EP7 bands of MW about 37 and $40 \mathrm{kDa}$ was indicated on cysteine proteinases enzymes (Fig. 2). From germinating barley grains, cysteine proteinase of
MW $31 \mathrm{kDa}$ was purified and $4.4 \mathrm{p} I$ was detected by 2D zymography (Zhang and Jones 1996). In broccoli florets, cysteine proteinase bands of 48 and $44 \mathrm{kDa}$ and $\mathrm{pI} 4.4$ and 4.2 were detected. By 2D zymography, 11 cysteine proteinases were revealed using $7 \mathrm{M}$ instead of $4 \mathrm{M}$ urea in strip rehydratation solution. Those conditions conversely influenced the irreversible denaturation of serine proteinases and metalloproteinases, which disappeared from zymograms (Rossano et al. 2011). In kiwi fruits, 33.8, 32.2, and $31.4 \mathrm{kDa}$ bands of cysteine proteinases at $\mathrm{p} I 3.92$ (Larocca et al. 2010) as well as a wide band of actinitin of MW about $30 \mathrm{kDa}$ (Afshar-Mohammadian et al. 2011) were found. Maciel et al. (2011) detected a $29 \mathrm{kDa}$ proteinase having acidic optimal $\mathrm{pH}$ and the $38 \mathrm{kDa}$ proteinase with neutral optimum activity in wounded and methyl jasmonate-treated leaves of Ricinus communis (L.). Induction of those isoforms by jasmonate suggested a possible role of cysteine proteases in leaf senescence. Intensive experiments and in silico studies by van der Hoorn group resulted in classification of 723 plant papainlike cysteine proteinases available in MEROPS DB, into 
nine subfamilies (Richau et al. 2012). Those enzymes are highly resistant, which allows them to act in proteolytically harsh environments of apoplasts, vacuoles, or lysosomes during cell aging or apoptosis. Most known proteases: SAG12 (Grbić 2003) and RD21 (Hara-Nishimura et al. 1995) have been structurally characterized as having double cysteine or two subfamily-specific disulfides in the catalytic site, respectively (Richau et al. 2012; Misas-Villamil et al. 2013).

Side-by-side comparison of $1 \mathrm{D}$ and 2D gels made it possible to identify various proteinase families on $2 \mathrm{D}$ gels. Metalloproteinase isoforms visible on the top of the gel in the range 4.5-6.0 $\mathrm{p} I$ were counted as seven spots. Aspartic proteinases of 115-118 $\mathrm{kDa}$ showed 10 spots in the same range of $\mathrm{p} I$. Ten serine proteinase spots were assigned to molecular weight of $80 \mathrm{kDa}$ (two spots) and $70 \mathrm{kDa}$ (eight spots). Also cysteine proteinases were shown to be presented in two separate subfamilies of 37 and $40 \mathrm{kDa}$.

There are various techniques available for proteinases identification and characterization, among which zymography has been one of leading due to feasibility of active isoform isolation from the gel (Vandooren et al. 2013). Zymography, especially when run on $1 \mathrm{D}$ gels, is a relatively inexpensive technique, which requires only specific inhibitors of costly reagents. Both variants $1 \mathrm{D}$ and $2 \mathrm{D}$, if used in combination with other techniques, help in understanding the functions of the enzyme of interest in various physiological processes (Vandooren et al. 2013). In studies of wheat resistance to abiotic stresses inducing tissue dehydration, zymography can be used for detection of proteolytic enzymes (Grudkowska and Zagdanska 2004). While in response to abiotic stress, there is a need to degrade of redundant, misfolded or damaged protein; proteinases play the main role conducting proteolysis, a chemical reaction that breaks peptide bonds releasing peptides and amino acids. Under environmental conditions inducing tissue dehydration (mainly drought, cold, frost) proteome rebuilding is an important mechanism of plant restoration and tissues homeostasis maintenance. Use of zymography allows the identification of enzyme families on 1D zymograms and number of proteinase subfamilies and clans using 2D gels (Rawlings et al. 2012).

Author contribution MG and KR declare equal participation in the implementation of the work. PL, the MSc student, was guided in carrying out part of experiments.

Acknowledgments Experiments were financed by grant of NCN, National Science Center of Poland, NN310 079839.

Open Access This article is distributed under the terms of the Creative Commons Attribution License which permits any use, distribution, and reproduction in any medium, provided the original author(s) and the source are credited.

\section{References}

Afshar-Mohammadian M, Rahimi-Koldeh J, Sajedi R (2011) The comparison of protease activity and total protein in three cultivars of kiwifruit of Northern Iran during fruit development. Acta Physiol Plant 33:343-348. doi:10.1007/s11738-010-0553-3

Cazenave C, Toulme JJ (2001) Gel renaturation assay for ribonucleases. In: Nicholson AW (ed) Methods of enzymology, vol 341. Academic Press, New York, pp 126-141. doi:10.1016/S00766879(01)41149-9

Chi W, Sun X, Zhang L (2012) The roles of chloroplast proteases in the biogenesis and maintenance of photosystem II. Biochim Biophys Acta Bioenerg 1817:239-246. doi:10.1016/j.bbabio. 2011.05.014

Chichkova NV, Tuzhikov AI, Taliansky M, Vartapetian AB (2012) Plant phytaspases and animal caspases: structurally unrelated death proteases with a common role and specificity. Physiol Plant 145:77-84. doi:10.1111/j.1399-3054.2011.01560.x

Cho CW, Chung E, Kim K et al (2009) Plasma membrane localization of soybean matrix metalloproteinase differentially induced by senescence and abiotic stress. Biol Plant 53:461-467. doi:10. 1007/s10535-009-0086-z

George S, Johnson J (2010) In Situ zymography. In: Clark IM (ed) Matrix metalloproteinase protocols, vol 622. Humana Press, New Jersey, pp 271-277. doi:10.1007/978-1-60327-299-5_17

Grbić V (2003) SAG2 and SAG12 protein expression in senescing Arabidopsis plants. Physiol Plant 119:263-271. doi:10.1034/j. 1399-3054.2003.00168.x

Grudkowska M, Zagdanska B (2004) Multifunctional role of plant cysteine proteinases. Acta Biochim Pol 51:609-624

Grudkowska M, Zagdanska B (2010) Acclimation to frost alters proteolytic response of wheat seedlings to drought. J Plant Physiol 167:1321-1327. doi:10.1016/j.jplph.2010.05.019

Hara-Nishimura I, Shimada T, Hiraiwa N, Nishimura M (1995) Vacuolar processing enzyme responsible for maturation of seed protein. J Plant Physiol 145:6412-6417. doi:10.1016/S01761617(11)81275-7

Hawkes S, Li H, Taniguchi G (2010) Zymography and reverse zymography for detecting MMPs and TIMPs. In: Clark IM (ed) Matrix metalloproteinase protocols, vol 622. Humana Press, New Jersey, pp 257-269. doi:10.1007/978-1-60327-299-5_16

Janska H, Kwasniak M, Szczepanowska J (2013) Protein quality control in organelles-AAA/FtsH story. Biochim Biophys ActaMol Cell Res 1833:381-387. doi:10.1016/j.bbamcr.2012.03.016

Joo AR, Jeya M, Lee KM, Sim WI, Kim JS, Kim IW, Kim YS, Oh DK, Gunasekaran P, Lee JK (2009) Purification and characterization of a beta-1,4-glucosidase from a newly isolated strain of Fomitopsis pinicola. Appl Microbiol Biot 83:285-294. doi:10. 1007/s00253-009-1861-7

Kwon M-A, Kim HS, Hahm D-H, Song JK (2011) Synthesis activitybased zymography for detection of lipases and esterases. Biotechnol Lett 33:741-746. doi:10.1007/s10529-010-0485-4

Lantz MS, Ciborowski P (1994) Zymographic techniques for detection and characterization of microbial proteases. In: Clark VL, Bavoil PM (eds) Methods of enzymology, vol 235. Academic Press, New York, pp 563-594. doi:10.1016/00766879(94)35171-6

Larocca M, Rossano R, Riccio P (2010) Analysis of green kiwi fruit (Actinidia deliciosa cv. Hayward) proteinases by two-dimensional zymography and direct identification of zymographic spots by mass spectrometry. J Sci Food Agric 90:2411-2418. doi:10.1002/jsfa.4100

Lucinski R, Jackowski G (2013) AtFtsH heterocomplex-mediated degradation of apoproteins of the major light harvesting complex 
of photosystem II (LHCII) in response to stresses. J Plant Physiol 170:1082-1089. doi:10.1016/j.jplph.2013.1003.1008

Maciel F, Salles CC, Retamal C, Gomes V, Machado OT (2011) Identification and partial characterization of two cysteine proteases from castor bean leaves (Ricinus communis L.) activated by wounding and methyl jasmonate stress. Acta Physiol Plant 33:1867-1875. doi:10.1007/s11738-011-0730-z

Marek L (2013) The role of the apoptosome in the activation of procaspase-9. Postep Hig Med Dosw 67:54-64 (in Polish)

Mariano G, Funk C (2012) Matrix metalloproteinases in plants: a brief overview. Physiol Plant 145:196-202. doi:10.1111/j.13993054.2011.01544.x

Misas-Villamil JC, Toenges G, Kolodziejek I, Sadaghiani AM, Kaschani F, Colby T, Bogyo M, Van Der Hoorn RAL (2013) Activity profiling of vacuolar processing enzymes reveals a role for VPE during oomycete infection. Plant J 73:689-700. doi:10. $1111 /$ tpj.12062

Ouyang L, Shi Z, Zhao S, Wang FT, Zhou TT, Liu B, Bao JK (2012) Programmed cell death pathways in cancer: a review of apoptosis, autophagy and programmed necrosis. Cell Prolif 45:487-498. doi:10.1111/j.1365-2184.2012.00845.x

Pan D, Hill AP, Kashou A, Wilson KA, Tan-Wilson A (2011) Electrophoretic transfer protein zymography. Anal Biochem 411:277-283. doi:10.1016/j.ab.2011.01.015

Paparelli E, Gonzali S, Parlanti S, Novi G, Giorgi FM, Licausi F, Kosmacz M, Feil R, Lunn JE, Brust H, van Dongen JT, Steup M, Perata P (2012) Misexpression of a chloroplast aspartyl protease leads to severe growth defects and alters carbohydrate metabolism in Arabidopsis. Plant Physiol 160:1237-1250. doi:10. 1104/pp.112.204016

Piechota J, Kolodziejczak M, Juszczak I, Sakamoto W, Janska H (2010) Identification and characterization of high molecular weight complexes formed by matrix AAA proteases and prohibitins in mitochondria of Arabidopsis thaliana. J Biol Chem 285:12512-12521. doi:12510.11074/jbc.M12109.063644

Piszczek E, Dudkiewicz M, Sobczak M (2011) Molecular cloning and phylogenetic analysis of cereal type II metacaspase cDNA from wheat. Biol Plant 55:614-624. doi:10.1007/s10535-011-0159-7

Piszczek E, Dudkiewicz M, Mielecki M (2012) Biochemical and bioinformatic Characterization of type ii metacaspase protein (TaeMCAII) from wheat. Plant Mol Biol Rep 30:1338-1347. doi:10.1007/s11105-012-0450-6

Rawlings ND, Barrett AJ, Bateman A (2012) MEROPS: the database of proteolytic enzymes, their substrates and inhibitors. Nucleic Acids Res 40:D343-D350 (http://merops.sanger.ac.uk). doi:10. 1093/nar/gkr987

Richau KH, Kaschani F, Verdoes M, Pansuriya TC, Niessen S, Stüber K, Colby T, Overkleeft HS, Bogyo M, van der Hoorn RAL (2012) Subclassification and biochemical analysis of plant papain-like cysteine proteases displays subfamily-specific characteristics. Plant Physiol 158:1583-1599. doi:10.1104/pp.112. 194001

Robinson DB, Glew RH (1980) Acid phosphatase in Gaucher's disease. Clin Chem 26:371-382

Rossano R, Larocca M, Riccio P (2011) 2-D zymographic analysis of broccoli (Brassica oleracea, L. var. Italica) florets proteases: follow up of cysteine protease isotypes in the course of postharvest senescence. J Plant Physiol 168:1517-1525. doi:10.1016/ j.jplph.2011.02.013

Royer JC, Nakas JP (1990) Simple, sensitive zymogram technique for detection of xylanase activity in polyacrylamide gels. Appl Environ Microbiol 56:1516-1517

Sakamoto K, Toyohara H (2009) A comparative study of cellulase and hemicellulase activities of brackish water clam Corbicula japonica with those of other marine Veneroida bivalves. J Exp Biol 212:2812-2818. doi:10.1242/jeb.031567

Shrestha A, Megeney L (2012) The non-death role of metacaspase proteases. Front Oncol 2:78. doi:10.3389/fonc.2012.00078

Shukla MR, Yadav R, Desai A (2009) Catalase and superoxide dismutase double staining zymogram technique for Deinococcus and Kocuria species exposed to multiple stresses. J Basic Microbiol 49:593-597. doi:10.1002/jobm.200900037

Srivalli B, Khanna-Chopra R (2001) Induction of new isoforms of superoxide dismutase and catalase enzymes in the flag leaf of wheat during monocarpic senescence. Biochem Biophys Res Commun 288:1037-1042. doi:0.1006/bbrc.2001.5843

Srivastava A, Nair J, Bendigeri D, Vijaykumar A, Ramaswamy N, D'Souza S (2009) Purification and characterization of a salinity induced alkaline protease from isolated spinach chloroplasts. Acta Physiol Plant 31:187-197. doi:10.1007/s11738-008-0219-6

Steup M, Gerbling K (1983) Multiple forms of amylase in leaf extracts: electrophoretic transfer of the enzyme forms into amylose-containing polyacrylamide gels. Anal Biochem 134:96-100. doi:10.1016/0003-2697(83)90268-3

Tamura T, Terauchi K, Kiyosaki T, Asakura T, Funaki J, Matsumoto I, Misaka T, Abe K (2007) Differential expression of wheat aspartic proteinases, WAP1 and WAP2, in germinating and maturing seeds. J Plant Physiol 164:470-477. doi:10.1016/j. jplph.2006.02.009

Tsiatsiani L, Van Breusegem F, Gallois P, Zavialov A, Lam E, Bozhkov P (2011) Metacaspases. Cell Death Differ 18:1279-1288. doi:10.1038/cdd.2011.66

Vandooren J, Geurts N, Martens E, Van den Steen PE, Opdenakker G (2013) Zymography methods for visualizing hydrolytic enzymes. Nat Methods 10:211-220. doi:10.1038/nmeth.237

Wagner R, Aigner H, Funk C (2012) FtsH proteases located in the plant chloroplast. Physiol Plant 145:203-214. doi:10.1111/j. 1399-3054.2011.01548.x

Wang J, Bayles KW (2013) Programmed cell death in plants: lessons from bacteria? Trends Plant Sci 18:133-139. doi:10.1016/j. tplants.2012.09.004

Wilkesman JG, Schroder HC (2007) Analysis of serine proteases from marine sponges by 2-D zymography. Electrophoresis 28:429-43610. doi:1002/elps.200600332

Zhang N, Jones BL (1995) Characterization of germinated barley endoproteolytic enzymes by two-dimensional gel electrophoresis. J Cereal Sci 21:145-153. doi:10.1016/0733-5210(95)90030-6

Zhang N, Jones BL (1996) Purification and partial characterization of a 31-kDa cysteine endopeptidase from germinated barley. Planta 199:565-572. doi:10.1007/bf00195188 